\title{
IMPORTANCE OF BIFID MANDIBULAR CANAL IN IMPLANTOLOGY AND IN ORAL SURGERY: REVIEW OF THE LITERATURE AND REPORT OF THREE CASES
}

\author{
Bifid Mandibuler Kanalin Implantoloji ve Oral Cerrahideki Önemi: \\ Üç Vaka Raporu ile Birlikte Literatürün Gözden Geçirilmesi
}

\author{
Nihat AKBULUT ${ }^{1}$, Sibel AKBULUT ${ }^{2}$, Bengi ÖZTAŞ ${ }^{3}$ \\ Şebnem KURŞUN ${ }^{3}$, Emrah SOYLU ${ }^{1}$, Orhan GÜVEN ${ }^{4}$
}

$\begin{array}{ll}\text { Makale Kodu/Article Code } & : 129166 \\ \text { Makale Gönderilme Tarihi } & : 07.06 .2015 \\ \text { Kabul Tarihi } & : 06.03 .2017\end{array}$

\section{ABSTRACT}

The mandibular canal or the inferior alveolar canal typically extends from the mandibular foramen to the mental foramen and includes the inferior alveolar artery, vein and the inferior alveolar nerve. During embryonic development three canals fuse to form a single canal. Failure of these canals to fuse can explain presence of multiple canals in some individuals. It is important to localize the course of the mandibular canal at the site of implant placement as altered sensation of the inferior lip due to inferior alveolar nerve injury. It is one of the most serious complication of mandibular implant surgery. Also the difficulty in performing mandibular anesthesia is the other problematic issue for patients and the clinicians.

The purpose of this study is to call attention to a rare anatomical variation. This case report reveals an unusual variant of the bifid mandibular canals. Three new cases, two of which are in the same family, have been presented.

Key words: Bifid mandibular canal, implant surgery, third molar extraction, inferior alveolar nerve, mandibular canals

\section{ÖZ}

Mandibuler kanal veya inferior alveoler kanal inferior alveoler arter, ven ve inferior alveoler siniri içerecek şekilde tipik olarak mandibuler foramenden mental foramene kadar uzanır. Emriyolojik gelişim sırasında üç kanal tek bir kanal formu şeklinde füzyona uğrar. $\mathrm{Bu}$ kanalların füzyona uğramasındaki başarısızlık bazı bireylerdeki çoklu kanalların varlığını açıklayabilir. İnferior alveoler sinir yaralanması sebebiyle alt dudak duyu değişikliğinde olduğu gibi implant yerleşim bölgesindeki mandibuler kanalın seyrinin lokalizasyonu önemlidir. Bu, mandibuler implant cerrahisinin çok ciddi komplikasyonundan biridir. Aynı zamanda mandibuler anestezi uygulamasındaki zorluk, hastalar ve klinisyenler için başka bir problematik bir konudur.

$\mathrm{Bu}$ çalışmanın amacı nadir görülen bir anatomik varyasyona dikkat çekmektir. $\mathrm{Bu}$ vaka raporu bifid mandibuler kanalların alışılmamış varyantını ortaya çıkarmaktadır. Üç yeni vaka, ikisi aynı aileden olmak üzere, sunulmuştur.

Anahtar kelimeler: Bifid mandibuler kanal, implant cerrahisi, üçüncü molar çekimi, inferior alveoler sinir, mandibuler kanallar

\footnotetext{
${ }^{1}$ University of Gaziosmanpaşa, School of Dentistry, Department of Oral and Maxillofacial Surgery, Tokat, Turkey.

${ }^{2}$ University of Gaziosmanpaşa, School of Dentistry, Department of Orthodontics, Tokat, Turkey.

${ }^{3}$ University of Ankara, School of Dentistry, Department of Oral and Maxillofacial Radiology, Ankara, Turkey.

${ }^{4}$ University of Ankara, School of Dentistry, Department of Oral and Maxillofacial Surgery, Ankara, Turkey.
} 


\section{INTRODUCTION}

Mandibular canal is usually seen as a single channel, enclosed by bony tissue, forming an upward concave curve. ${ }^{1}$ The canal which houses the inferior alveolar nerve and blood vessels, begins at the mandibular foramen, curves downward and forward, and turns into a horizontal course below the roots of the molars. In the region of premolars the mandibular canal splits into two canals of unequal width: the narrower incisive canal continues the course toward the midline; the wider branch, the mental canal, turns laterally, superiorly, and posteriorly to open at the mental foramen. ${ }^{2}$ In medical imaging, its appearance has been described as "a radiolucent dark ribbon between two white lines". 3

Bifid mandibular canal needs a special attention in oral surgical interventions. Some complications such as damage to accessorial canal, bleeding and traumatic neuroma may occur during the placement of dental implants. Nerve damage can arise as a consequence of inferior alveolar nerve anatomical variation; or the excessive intrusion of drills or implant fixture into the mandibular canal. ${ }^{4}$ Also possible complications may occur during regional anesthesia of the mandible, surgery of the lower third molar and orthognatic or reconstructive mandibular surgery. 5,6

The term bifid is derived from the Latin word meaning cleft into 2 parts of branches. ${ }^{6}$ The various types of bifid mandibular canals have been classified according to anatomical location and configuration. ${ }^{7,8}$ Bifid mandibular canal was first described and classified by Nortje et $a .^{7}$ as an important variation of the mandibular canal (Table 1). Later, Langlais et $a l .{ }^{8}$ reported another classification for the variation of bifid mandibular canal.
Table 1 Classification of Nortje et al. ${ }^{7}$

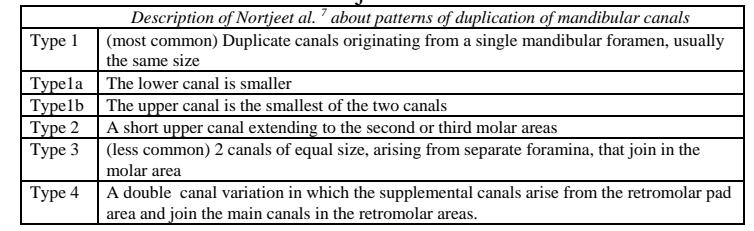

Three distinct inferior dental nerve branches, innervate three groups of mandibular teeth; incisors, primary and permanent molars - are fused together during embryonic development to form a single nerve branch. During rapid prenatal growth and remodeling in the ramus region there is spread of intramembranous ossification that eventually forms the mandibular canal. Occurrence of bifid or trifid mandibular canals in some patients is secondary to incomplete fusion of these three inferior dental nerves. ${ }^{9,} 10$

The purpose of this study is to particularly call attention to a rare anatomical variation. Bifid mandibular canals have been observed on panoramic radiographs. This report also, is including three new cases, deals with unusual variants of the bifid mandibular canals.

\section{CASE REPORTS}

\section{Case 1 and Case 2}

Case 1; A 25-year-old woman was referred to the dentistry school with some dental problems. Medical history revealed that the patient was in excellent health. On the routine panoramic radiographic examination (Figure1a), bifid mandibular canal was observed on the right side of the mandible. The type of the bifid mandibular canal was similar to Type 2 according to the Nortje's ${ }^{7}$ classification (Figure 1b). Short lower canal had extended to the second and third molar areas. Computed tomography (CT) evaluation confirmed the existence of bifid mandibular canal (Figure2). Panoramic radiographs of the other members of the family were taken in order to analyse the effect of genetics on bifid mandibular canal. 


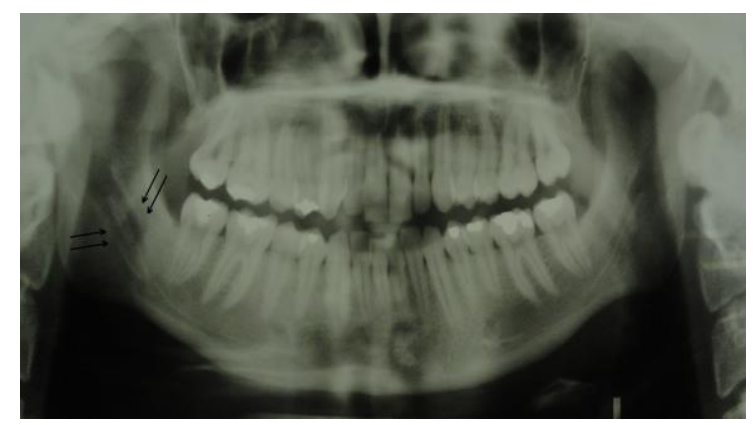

Figure 1a. Panoramic radiograph (*Black arrows show the bifid mandibular canal).

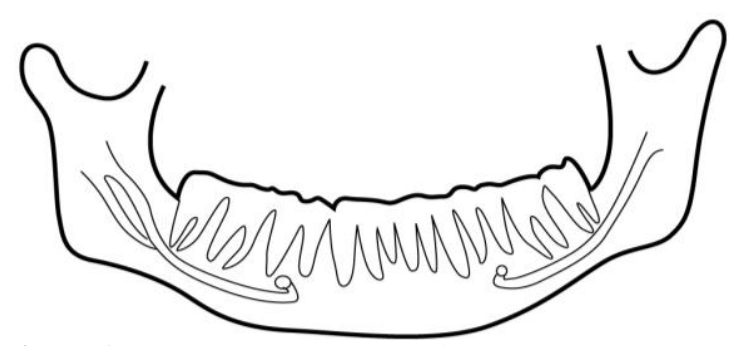

Figure 1b. Diagrammatic picture of landmarks, constructed points and lines used to identify the bifid mandibular canal of Case 1.

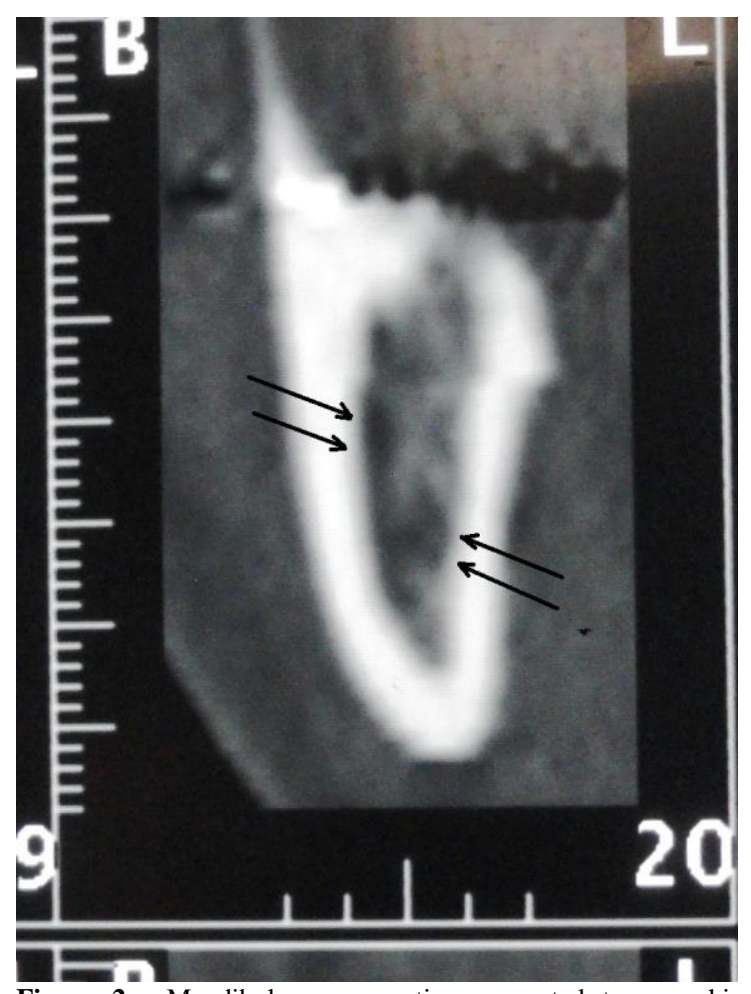

Figure 2. Mandibular cross-section computed tomographic image showing the bifid mandibular canal of case 1 (*Black arrows showe the bifid mandibular canal).

Case 2; Examination of radiographs revealed the presence of unilateral double canal on the right side of the mandible of the mother of patient No: 1 (Figure 3a). The type of the mandibular canal was similar to Type 2 as described by Nortje et al. ${ }^{7}$ (Figure 3b). Her medical history was quite well, whereas her dental history revealed difficulties in performing mandibular anesthesia in the past during the course of a medical treatment.

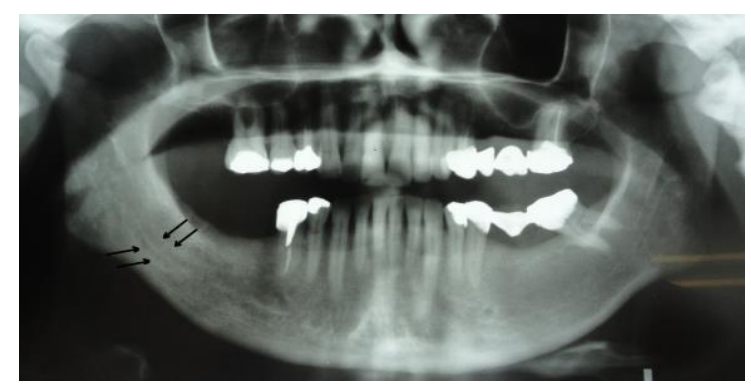

Figure 3a. Panoramic radiograph (*Black arrows showe the bifid mandibular canal).

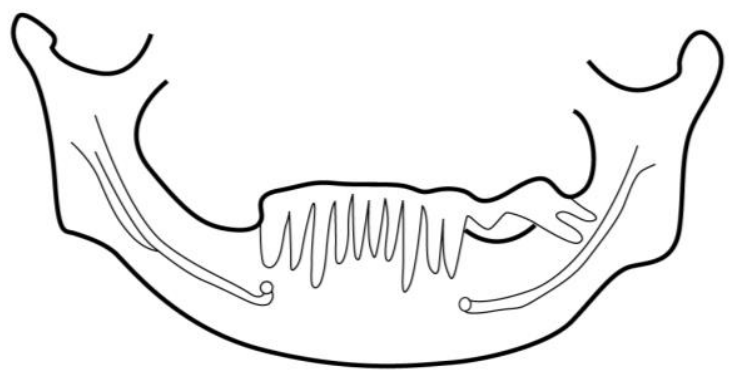

Figure 3b. Diagrammatic picture of landmarks, constructed points and lines used to identify the bifid mandibular canal of case 2 .

\section{Case 3}

A 58-year-old man was referred to the dentistry school for prosthetic rehabilitation with the dental implant supported restoration. Medical history indicated that the patient had diabetes however well-controlled. On the routine panoramic radiograph, bifid mandibular canal was observed bilaterally on the right and left side of the mandible (Figure 4a). The types of the canals were Type 2 according to the classification of Nortje et al. ${ }^{7}$ His dental history revealed difficulty in performing mandibular anesthesia during surgical removal of the right lower teeth. The patient was informed about the complications of anesthesia before implant surgery and thereupon he refused the treatment. 


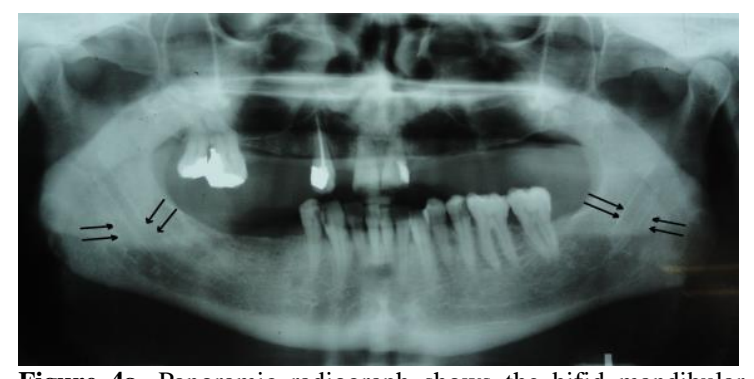

Figure 4a. Panoramic radiograph shows the bifid mandibular canal (*black arrows showe the bifid mandibular canal).

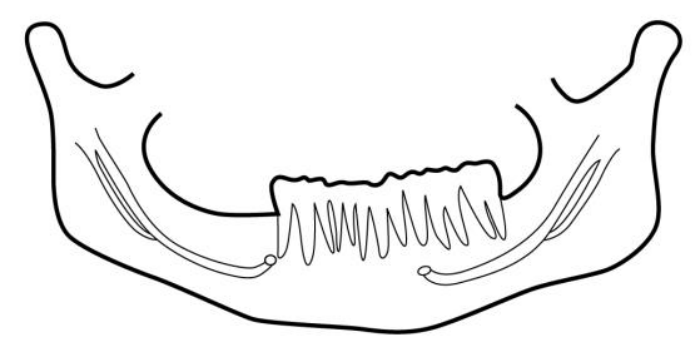

Figure 4b. Diagrammatic picture of landmarks, constructed points and lines used to identify the bifid mandibular canal of case 3.

\section{DISCUSSION}

Several studies on panoramic evaluation and incidence of bifid mandibular canal have been reported. $^{7}, 8,11,12$ Durst and Snow ${ }^{11}$ have examined 1024 panoramic radiographs and found the $8.3 \%$ bifid canals, Nortje et al. ${ }^{7}$ have examined 3612 panoramic radiographs and found $0.9 \%$ bifid mandibular canals. Langlais et al. ${ }^{8}$ have stated a similar prevalence of bifid canals $(0.9 \%)$ based on an analysis of 6000 radiographs. Grover and Lorton ${ }^{12}$ have reported a prevalance only $0.08 \%$ after examining 5000 panoramic radiographs. In our study 950 panoramic radiographs have been examined and four bifid canals in three patients were found $(0.4 \%)$. Also Nortje et al. ${ }^{7}$ and Langlais et $a l .{ }^{8}$ have classified bifid mandibular canal variants by slightly different criteria. The cases in this study seem to somewhat fit to Type 2 described by Nortjé. ${ }^{7}$ Nevertheless, taking into account the distinction in canal variations, these cases may be defined as a different, and apparently new, variant.

Bifid mandibular canals were seen unilaterally and bilaterally almost at the same frequency. ${ }^{7,}{ }^{8}$ In this study, two cases (Patient
No: 1 and 2) had unilateral bifid mandibular canals whereas that of the third was bilateral.

It has been claimed that bifid mandibular canals occur more frequently in females.6, 7, 13 An interesting variation of the mandibular canal has been reported by Auluck et al. ${ }^{6,14}$ who have recently described a case of a triple mandibular canal in a 20-year-old patient, where the third branch perforated the lingual cortex in the retromolar area.

Damage to the nerve and inadequate anesthesia are the most common problems encountered in patients with bifid mandibular nerve canals. ${ }^{6}$ In this study, Patient No: 2 and 3 had had the difficulty of mandibular anesthesia during dental treatment. This problem is usually resolved by performing inferior alveolar nerve anesthesia at a higher level, before the bifurcation of the mandibular nerve. This technique is called "Gow-Gates" technique. ${ }^{6,13}$

Clinicians should be cautious during the course of the third molar surgery. The tooth may infringe on or be within the canal itself. A second neurovascular bundle may exist within the bifid canals; complications such as traumatic neuroma, paresthesia and bleeding may arise if the presence of this anomaly is overlooked and/or underestimated. ${ }^{9}$

Other complications may occur during the process of orthognathic or reconstructive mandibular surgery. Especially, bifid mandibular canals need particular attention in dental implantology. Surgeon must have a detailed examination of patient before placement of implant; in cases with bifid mandibular canal due to possible damage to the second mandibular canal. ${ }^{5,10}$ Kiyak et al. ${ }^{14}$ reported $43.5 \%$ paresthesia 2 weeks after mandibular implant placement; Bartling et al. ${ }^{15}$ reported $8.5 \%$ of patients with altered sensation and Ellies $^{16}$, in a retrospective questionnaire addressing sensory changes, recorded $37 \%$ of altered sensation 1 month after implant placement. ${ }^{14,15,16}$ 
Another probable complication is alveolar bone resorption in the proximity of the mental foramen; patients with a mandibular prosthesis experience pain because of the pressure on the neurovascular bundle. Such a problem can be encountered in cases of bifid mandibular canal with branches extending to the third molar and retromolar pad areas. Therefore, awareness of this probable anomaly will enable the clinician to modify the prosthetic design and impression techniques. ${ }^{17,18}$

The patients No: 1 and 2 had had an interesting clinical and radiographic situation which was presence of the bifid canal both in daughter and the mother. Panoramic radiograph was not sufficient to conclude whether the pathologic condition has a genetic character or not. Further studies should be carried out in order to check the genetical tendency of bifid mandibuler canals.

It is important for dentists to identify the presence of bifid canals to modify anaesthetic techniques to avoid pain and discomfort to patients. Therefore identification of such variations in patterns of mandibular nerve canal is of considerable interest to dentists.

\section{REFERENCES}

1. Rouas P, Nancy J, Bar D. Identification of double mandibular canals: literature review and three case reports with CT scans and cone beam CT. Dentomaxillofac Radiol 2007; 36: 34-38.

2. Sicher H, Dubrul EL. Oral Anatomy. USA, Mosby Co.Sixth edition. 1975 pp. 53.

3. Worth HM. Normal radiographic appearances of the teeth and jaws and variations within the normal. Principals and practice of oral radiologic interpretation. Chicago, IL: Year Book Medical Publishers, Inc.;1963, pp 15-79.

4. Lamas Pelayo J, Peñarrocha Diago $M$, Martí Bowen E, Peñarrocha Diago $M$. Intraoperative complications during oral implantology. Med Oral Patol Oral Cir Bucal. 2008; 13: E239-43.

5. Karamifar K, Shahidi S, Tondari A. Bilateral bifid mandibular canal: report of two cases. Indian J Dent Res. 2009; 20: 235-7.

6. Auluck A, Mupparapu M. Multiple mandibular nerve canals: Radiographic observations and clinical relevance. Report of 6 cases. Quintessence Int 2007; 38: 781-787.

7. Nortje CJ, Farman AG, Grotepass FW. Variation in the normal anatomy of inferior dental (mandibular) canal: A retrospective study of panoramic radiographs from 3612 routine dental patients. Br J Oral Surg 1977; 15(1)55-63.

8. Langlais RP, Broadus R, Glass BJ. Bifid mandibular canals in panoramic radiographs. $J$ Am Dent Assoc 1985; 110:923-926.

9. Wadhwani P, Mathur RM, Kohli M, Sahu R. Mandibular canal variant:a case report. J Oral Pathol Med 2008; 37: 122-124.

10.Chávez-Lomeli ME, Mansilla Lory J, Pompa JA, Kjaer I. The human mandibular canal arises from three separate canals innervating different tooth groups. J Dent Res. 1996 Aug;75(8):1540-4

11.Durst JH, Snow JE. Multiple mandibular canals: oddities or fairly common anomalies? Oral Surg Oral Med Oral Pathol 1980; 49: 272-273.

12. Grover PS, Lorton L. Bifid mandibular nerve as a possible cause of inadequate anaesthesia in the mandible. J Oral Maxillofac Surg 1983; 41: 177-179.

13. Sanchis JM, Penarrocha M, Soler F. Bifid mandibular canal. J Oral Maxillofac Surg 2003;61: 422-424.

14.Kiyak, H.A., Beach, B.H., Worthington, P., Taylor, T., Bolender, C. \& Evans, J. (1990) Psychological impact of osseointegrated dental implants. International Journal of Oral and Maxillofacial Implants 5: 61-69. 
15.Bartling, R., Freeman, K. \& Kraut, R.A. (1999) The incidence of altered sensation of the mental nevre after mandibular implant placement. Journal of Oral and Maxillofacial Surgery 57: 1408-1412.

16.Ellies, L.G. (1992) Altered sensation followingmandibular implant surgery: a retrospective study. Journal of Prosthetic Dentistry 68: 664-671.

17.Auluck A, Ahsan A, Pai KM, Shetty C. Anatomical variations in developing mandibular nerve canal: a report of three cases. Neuroanatomy 2005; 4:28-30.
18. Meechan JG. How to over come failed local anaesthesia. Br. Dent. J. 1999; 186: 15-20.

\section{Correspondence Author}

Nihat AKBULUT

Department of Oral and Maxillofacial Surgery

Faculty of Dentistry

University of Gaziosmanpasa

Tokat, Turkey.

Phone: + 905054489263

Fax: + 903562124222

E-mail: drnihatakbulut@yahoo.com 